Case Study

\title{
Correlation between waist and mid-thigh circumference and cardiovascular fitness in Korean college students: a case study
}

\author{
Sung-SiK Ko, $\mathrm{PhD}^{1)}$, Jae-Soon Chung, PhD ${ }^{1)}$, Wi-Young So, $\mathrm{PhD}^{1)^{*}}$ \\ 1) College of Humanities and Arts, Sports and Health Care Major, Korea National University of \\ Transportation: 50 Daehak-ro, Chungju-si, Chungbuk 380-702, Republic of Korea
}

\begin{abstract}
Purpose] We investigated whether waist and mid-thigh circumference correlated with cardiovascular fitness $\left(\mathrm{VO}_{2} \mathrm{max}\right)$ in a selected sample of Korean college students. [Subjects and Methods] The subjects were 41 college students ( 25 males, 16 females; age, > 19 years) who visited the sports medicine laboratory at the Korea National University of Transportation in Chungju-si, Republic of Korea, to undergo measurements of body composition, cardiovascular fitness, and waist and mid-thigh circumference. [Results] $\mathrm{VO}_{2}$ max did not correlate with waist circumference or mid-thigh circumference in males, whereas $\mathrm{VO}_{2} \max$ was negatively correlated with mid-thigh circumference, but not waist circumference, in females. [Conclusion] Mid-thigh circumference was not associated with cardiovascular fitness or waist in male college students. However, it was associated with cardiovascular fitness in female college students. Well-designed studies are needed to investigate this further. Key words: Cardiovascular fitness, Mid-thigh circumference, Waist circumference
\end{abstract}

(This article was submitted Mar. 6, 2015, and was accepted Apr. 3, 2015)

\section{INTRODUCTION}

According to the 2013 Korea National Health and Nutrition Examination Survey, the prevalence of obesity was $37.6 \%$ in men and $25.1 \%$ in women aged $\geq 19$ years in the Republic of Korea ${ }^{1}$. This finding indicates that approximately one-third of Koreans are obese and that obesity is becoming a serious public, social, and national health issue in the Republic of Korea.

Obesity, particularly abdominal obesity, is strongly associated with an increased risk of cardiovascular disease, type-2 diabetes, hypertension, hyperglycemia, dyslipidemia, musculoskeletal diseases, genetic diseases, and some cancers $^{2,3)}$. Thus, it is important to prevent and treat chronic diseases, such as obesity, because the economic losses from chronic diseases are sufficient to cause social problems $\mathrm{s}^{4,5)}$.

Kim et al. ${ }^{6}$ demonstrated that low thigh muscle mass was closely associated with diabetes and preventing chronic disease. Since that study was published, many others have reported relationships between thigh muscle mass (or fat mass) and clinical predictors, such as the homeostasis model assessment-estimated insulin resistance, triglycerides, and total cholesterol ${ }^{7,8)}$.

A high fitness level or regular exercise is related to a low

*Corresponding author. Wi-Young So (E-mail: wowso@ut.ac. $\mathrm{kr})$

(C2015 The Society of Physical Therapy Science. Published by IPEC Inc. This is an open-access article distributed under the terms of the Creative Commons Attribution Non-Commercial No Derivatives (by-ncnd) License $<$ http://creativecommons.org/licenses/by-nc-nd/3.0/>. prevalence of chronic diseases, such as obesity and hypertension ${ }^{9-13)}$. In addition, low fitness is closely associated with mortality ${ }^{14)}$.

Many studies have reported that obesity, including abdominal obesity, is related to fitness level as well as chronic disease ${ }^{10)}$. Thus, in this pilot study, we investigated the relationship between waist circumference and cardiovascular fitness $\left(\mathrm{VO}_{2} \mathrm{max}\right)$. We also examined the relationship between thigh circumference and cardiovascular fitness $\left(\mathrm{VO}_{2} \mathrm{max}\right)$, because there is a reported relationship between thigh circumference and chronic disease, and fitness level is related to chronic disease.

\section{SUBJECTS AND METHODS}

\section{Subjects}

This study included 41 college students (25 males, 16 females; age, $>19$ years) who visited the Sports Medicine Laboratory at the Korea National University of Transportation in Chungju-si, Republic of Korea, to undergo measurements of body composition, cardiovascular fitness, and waist and mid-thigh circumference. All participants provided informed consent, and this study conformed to the principles outlined in the Declaration of Helsinki. The study design was approved by the Institutional Review Board at the Korea National University of Transportation (KNUT IRB-15).

The parameters measured included body composition (weight, percent body fat, and basal metabolic rate), cardiovascular fitness $\left(\mathrm{VO}_{2} \mathrm{max}\right)$, waist circumference, and mid-thigh circumference. The body composition instrument (InBody 720, Biospace, Seoul, Republic of Korea) measured resistance of the arms, trunk, and legs at frequencies of 1, 5, 
3020 J. Phys. Ther. Sci. Vol. 27, No. 9, 2015

Table 1. Subjects' characteristics

\begin{tabular}{lccc}
\hline Variables & Male $(\mathrm{n}=25)$ & Female $(\mathrm{n}=16)$ & Total $(\mathrm{n}=41)$ \\
\hline Age $($ years $)$ & $22.6 \pm 1.2$ & $19.6 \pm 0.5$ & $21.4 \pm 1.7$ \\
Height $(\mathrm{cm})$ & $175.0 \pm 4.3$ & $162.2 \pm 3.9$ & $170.0 \pm 7.5$ \\
Weight $(\mathrm{kg})$ & $73.2 \pm 10.7$ & $59.5 \pm 8.1$ & $67.8 \pm 11.8$ \\
Body mass index $\left(\mathrm{kg} / \mathrm{m}^{2}\right)$ & $23.9 \pm 3.1$ & $22.6 \pm 2.7$ & $23.4 \pm 3.0$ \\
Body fat $(\%)$ & $16.9 \pm 5.5$ & $27.9 \pm 5.2$ & $21.2 \pm 7.6$ \\
Basal metabolic rate $(\mathrm{kcal})$ & $1,683.9 \pm 158.2$ & $1,288.1 \pm 85.4$ & $1,529.4 \pm 236.6$ \\
$\mathrm{VO}_{2}$ max $(\mathrm{ml} / \mathrm{kg} / \mathrm{min})$ & $47.7 \pm 4.9$ & $38.4 \pm 4.3$ & $44.1 \pm 6.5$ \\
Waist circumference $(\mathrm{cm})$ & $85.2 \pm 7.3$ & $76.8 \pm 6.3$ & $81.9 \pm 8.0$ \\
Mid-thigh circumference $(\mathrm{cm})$ & $59.4 \pm 6.2$ & $52.8 \pm 4.7$ & $56.5 \pm 6.2$ \\
\hline
\end{tabular}

Data are shown as the mean $\pm \mathrm{SD}$

50, 256, 512, and $1,024 \mathrm{kHz}$ through eight tactile electrodes: two in contact with the palm and thumb of each hand and two in contact with the anterior and posterior aspects of the sole of each foot ${ }^{15}$. All participants were prohibited from eating $4 \mathrm{~h}$ before, exercising $12 \mathrm{~h}$ before, and urinating just before the impedance measurements. The participants were told to wear light clothing and remove all metal items that could interrupt the electronic current during measurements. All methods used to assess body composition followed recommendations in the book Applied Body Composition Assessment ${ }^{16)}$. The body mass index (BMI, $\mathrm{kg} / \mathrm{m}^{2}$ ) of each participant was calculated based on weight, height, and body composition (weight, \% body fat, and basal metabolic rate).

Cardiovascular fitness $\left(\mathrm{VO}_{2} \mathrm{max}\right)$ level was determined by a graded exercise test using a treadmill (Quark Series, P/N: C09073-02-99, Cosmed Cardiopulmonary Diagnostics, Rome, Italy). Maximum oxygen consumption was estimated by gradually increasing exercise intensity, starting from $2.74 \mathrm{~km} / \mathrm{h}$ at a gradient of $10 \%$. The treadmill incline was increased by $2 \%$ at 3 -min intervals according to the Bruce protoco ${ }^{17)}$. Maximum oxygen consumption, $\mathrm{VO}_{2} \max$, was recorded when the respiratory exchange rate was above 1.15 , there was plateau despite an increase in exercise intensity, the heart rate was $90 \%$ of the predicted heart rate maximum, or the subject needed to stop because of exhaustion.

Waist circumference was measured at the trunk midway between the lower costal margin (bottom of the lowest rib) and the iliac crest (top of the pelvic bone) with the subject standing with his/her feet $25-30 \mathrm{~cm}$ apart. Mid-thigh circumference was measured midway down the right leg. The measurement was taken by fitting the tape snugly, without compressing the underlying soft tissue. Circumference was measured to the nearest $0.5 \mathrm{~cm}$; at the end of a normal expiration.

All results are presented as means \pm standard deviations. According to the central limit theorem, if the number of participants in each group is $<30$, the data are likely to be unreliable and will likely not approximate a normal distribution $^{18)}$. Thus, we used the nonparametric Spearman's correlation analysis to examine the correlation between waist circumference and $\mathrm{VO}_{2}$ max and between mid-thigh circumference and $\mathrm{VO}_{2} \max$. A p value $<0.05$ was considered to indicate statistical significance. All analyses were performed using the PASW Statistics software (ver. 18.0; SPSS Inc.,
Table 2. Results of Spearman's correlation analysis for associations between waist and mid-thigh circumference and $\mathrm{VO}_{2} \max$

\begin{tabular}{lcc}
\hline \multirow{2}{*}{ Variables } & \multicolumn{2}{c}{$\mathrm{VO}_{2} \max (\mathrm{ml} / \mathrm{kg} / \mathrm{min})$} \\
\cline { 2 - 3 } & Male $(\mathrm{n}=25)$ & Female $(\mathrm{n}=16)$ \\
\hline & $\mathrm{r}$ & $\mathrm{r}$ \\
Waist circumference $(\mathrm{cm})$ & 0.237 & -0.185 \\
Mid-thigh circumference $(\mathrm{cm})$ & 0.189 & $-0.572 *$ \\
\hline
\end{tabular}

$* \mathrm{p}<0.05$, as determined by Spearman's correlation analysis

Chicago, IL, USA).

\section{RESULTS}

The subjects' characteristics are shown in Table 1. The mean age of the males $(n=25)$ was $22.6 \pm 1.2$ years, and that of the females $(n=16)$ was $19.6 \pm 0.5$ years. The mean height of the males was $175.0 \pm 4.3 \mathrm{~cm}$, and that of the females was $162.2 \pm 3.9 \mathrm{~cm}$. The mean weight of the males was $73.2 \pm 10.7 \mathrm{~kg}$, and that of the females was $59.5 \pm 8.1 \mathrm{~kg}$. The mean BMI of the males was $23.9 \pm 3.1 \mathrm{~kg} / \mathrm{m}^{2}$, and that of the females was $22.6 \pm 2.7 \mathrm{~kg} / \mathrm{m}^{2}$. The mean percent body fat of the males was $16.9 \pm 5.5 \%$, and that of the females was $27.9 \pm 5.2 \%$. The mean basal metabolic rate of the males was $1,683.9 \pm 158.2 \mathrm{kcal}$, and that of the females was $1,288.1 \pm 85.4 \mathrm{kcal}$. The mean $\mathrm{VO}_{2}$ max of the males was $47.7 \pm 4.9 \mathrm{~mL} \cdot \mathrm{kg}^{-1} \cdot \mathrm{min}^{-1}$, and that of the females was $38.4 \pm 4.3 \mathrm{~mL} \cdot \mathrm{kg}^{-1} \cdot \mathrm{min}^{-1}$. The mean waist circumference of the males was $85.2 \pm 7.3 \mathrm{~cm}$, and that of the females was $76.8 \pm 6.3 \mathrm{~cm}$. The mean mid-thigh circumference of the males was $59.4 \pm 6.2 \mathrm{~cm}$, and that of the females was $52.8 \pm 4.7 \mathrm{~cm}$.

The results of Spearman's correlation analysis for associations between waist circumference and $\mathrm{VO}_{2} \max$ and between mid-thigh circumference and $\mathrm{VO}_{2}$ max are shown in Table 2. $\mathrm{VO}_{2} \mathrm{max}$ in males did not correlate with waist circumference $(r=0.237, p=0.254)$ or mid-thigh circumference $(\mathrm{r}=0.189, \mathrm{p}=0.367)$. $\mathrm{VO}_{2} \mathrm{max}$ in females did not correlate with waist circumference $(r=-0.185, p=0.492)$, but it did correlate negatively with mid-thigh circumference $(\mathrm{r}=-0.572, \mathrm{p}=0.021)$. 


\section{DISCUSSION}

The purpose of this study was to examine the relationships between waist and mid-thigh circumference and cardiovascular fitness in Korean college students. The results show that cardiovascular fitness was only associated with thigh circumference in female students.

Many studies have reported that a large waist circumference and obesity are related to low fitness levels ${ }^{10,14)}$. However, this trend is prevalent in obese and elderly subjects due to aging. This finding suggests that a large waist circumference is related to low fitness levels in subjects in poor physical condition. We found no relationship between waist circumference and fitness level in young college students, indicating that total fat mass, rather than waist circumference, is related to fitness level.

Moreover, previous studies have demonstrated that low thigh muscle mass is related to chronic disease in obese subjects $^{6-8)}$. Nevertheless, we found no relationship between thigh circumference and fitness level in male college students with a relatively high fitness level. Interestingly, a small thigh circumference was correlated with a high fitness level in the female students, suggesting that a large thigh circumference in female college students reflects fat mass rather than muscle mass. Thus, a large thigh circumference may be related to a high fat mass, resulting in a low fitness level. Various authors have suggested that $\mathrm{VO}_{2}$ max is associated with the incidence of lifestyle-related diseases ${ }^{19,20)}$, all-cause mortality ${ }^{21-25)}$, and continued ability to perform aerobic activity ${ }^{26)}$; thus, it is important to maintain a healthy physical condition to improve fitness. Well-designed studies are necessary to study these factors.

This study had some limitations. Because the participants were recruited from one university in Chungju-si, Republic of Korea, they do not represent all Korean college students. Furthermore, we only evaluated a small number of students $(n=41)$; thus, the results may be unreliable. Moreover, because mid-thigh circumference is not completely representative of the level of thigh muscle mass (or fat mass), it lacks validation. Nevertheless, the major strength of this study was that it focused on determining if waist or mid-thigh circumference was correlated with cardiovascular fitness, which was investigated waist and mid-thigh circumference and cardiovascular fitness, which were investigated for the first time in Korea in this pilot study.

\section{REFERENCES}

1) Korea Centers for Disease Control and Prevention: Korea Health Statistics 2013, Korea National Health and Nutrition Examination Survey (KNHANES VI). Korea Centers for Disease Control and Prevention. https://knhanes.cdc.go.kr/knhanes/index.do (Accessed Feb. 28, 2015)

2) Naukkarinen J, Rissanen A, Kaprio J, et al.: Causes and consequences of obesity: the contribution of recent twin studies. Int J Obes, 2012, 36: 1017-1024. [Medline] [CrossRef]
3) Francischetti EA, Genelhu VA: Obesity-hypertension: an ongoing pandemic. Int J Clin Pract, 2007, 61: 269-280. [Medline] [CrossRef]

4) Thomas AW, Albert JS: Handbook of obesity treatment, 3rd ed. New York: Guilford Press, 2002.

5) Ford ES: Risks for all-cause mortality, cardiovascular disease, and diabetes associated with the metabolic syndrome: a summary of the evidence. Diabetes Care, 2005, 28: 1769-1778. [Medline] [CrossRef]

6) Kim D, Nam S, Ahn C, et al.: Correlation between midthigh low-density muscle and insulin resistance in obese nondiabetic patients in Korea. Diabetes Care, 2003, 26: 1825-1830. [Medline] [CrossRef]

7) Aasen G, Fagertun H, Halse J: Regional fat mass by DXA: high leg fat mass attenuates the relative risk of insulin resistance and dyslipidaemia in obese but not in overweight postmenopausal women. Scand J Clin Lab Invest, 2008, 68: 204-211. [Medline] [CrossRef]

8) Aasen G, Fagertun H, Tonstad S, et al.: Leg fat mass as measured by dual X-ray absorptiometry (DXA) impacts insulin resistance differently in obese women versus men. Scand J Clin Lab Invest, 2009, 69: 181-189. [Medline] [CrossRef]

9) Yoon JH, So WY: Relationship between hypertension status and physical fitness, including cardiovascular function, in Korean men. J Men's Health, 2013, 10: 28-36.

10) Kim JH, So WY: Associations between weight status and different types of physical fitness variables in Korean men: a community-based study. J Men's Health, 2013, 10: 60-64.

11) Yagura $\mathrm{C}$, Takamura N, Goto $\mathrm{Y}$, et al.: Cardiorespiratory fitness and metabolic markers in healthy young adult men. J Phys Ther Sci, 2011, 23: 845849. [CrossRef]

12) Hur S, Kim SR: The effects of exercise therapy on CVD risk factors in women. J Phys Ther Sci, 2014, 26: 1367-1370. [Medline] [CrossRef]

13) Lee EG, Choi JH, Kim KE, et al.: Effects of a walking program on selfmanagement and risk factors of metabolic syndrome in older Korean adults. J Phys Ther Sci, 2014, 26: 105-109. [Medline] [CrossRef]

14) Wei M, Kampert JB, Barlow CE, et al.: Relationship between low cardiorespiratory fitness and mortality in normal-weight, overweight, and obese men. JAMA, 1999, 282: 1547-1553. [Medline] [CrossRef]

15) Jensky-Squires NE, Dieli-Conwright CM, Rossuello A, et al.: Validity and reliability of body composition analysers in children and adults. Br J Nutr, 2008, 100: 859-865. [Medline] [CrossRef]

16) Heyward VH, Wagner DR: Applied body composition assessment, 2nd ed. Human Kinetics, 2004.

17) Bruce RA, Kusumi F, Hosmer D: Maximal oxygen intake and nomographic assessment of functional aerobic impairment in cardiovascular disease. Am Heart J, 1973, 85: 546-562. [Medline] [CrossRef]

18) Johnson RA, Bhattacharyya GK: Statistics: Principles and methods. New York: John Wiley, 2010.

19) Caballero B: Introduction. Symposium: obesity in developing countries: biological and ecological factors. J Nutr, 2001, 131: 866S-870S. [Medline]

20) Lee L: The current state of public health in China. Annu Rev Public Health, 2004, 25: 327-339. [Medline] [CrossRef]

21) Popkin BM, Doak CM: The obesity epidemic is a worldwide phenomenon. Nutr Rev, 1998, 56: 106-114. [Medline] [CrossRef]

22) Popkin BM, Gordon-Larsen P: The nutrition transition: worldwide obesity dynamics and their determinants. Int J Obes Relat Metab Disord, 2004, 28: S2-S9. [Medline] [CrossRef]

23) Qu JB, Zhang ZW, Shimbo S, et al.: Nutrient intake of adult women in Jilin Province, China, with special reference to urban-rural differences in nutrition in the Chinese continent. Eur J Clin Nutr, 2000, 54: 741-748. [Medline] [CrossRef]

24) Ojiambo RM, Easton C, Casajús JA, et al.: Effect of urbanization on objectively measured physical activity levels, sedentary time, and indices of adiposity in Kenyan adolescents. J Phys Act Health, 2012, 9: 115-123. [Medline]

25) Lambert EV, Lambert MI, Hudson $\mathrm{K}$, et al.: Role of physical activity for health in communities undergoing epidemiological transition. World Rev Nutr Diet, 2001, 90: 110-126. [Medline]

26) Sandvik L, Erikssen J, Thaulow E, et al.: Physical fitness as a predictor of mortality among healthy, middle-aged Norwegian men. N Engl J Med, 1993, 328: 533-537. [Medline] [CrossRef] 